BIP: Jurnal Bahasa Indonesia Prima

Vol. 3, No. 2, 2021, September 2021, PP.

\title{
PENGARUH PENGGUNAAN MEDIA LAGU FIERSA BESARI TERHADAP KEMAMPUAN MENULIS PUISI PADA SISWA KELAS X DI SMAN 19 BEKASI
}

\author{
Liza Zakiyah $^{1}$, Imam Muhtarom², Dewi Herlina Sugiarti ${ }^{3}$ \\ Universitas Singaperbangsa Karawang \\ Corresponding Author: lizazakiyah23@gmail.com
}

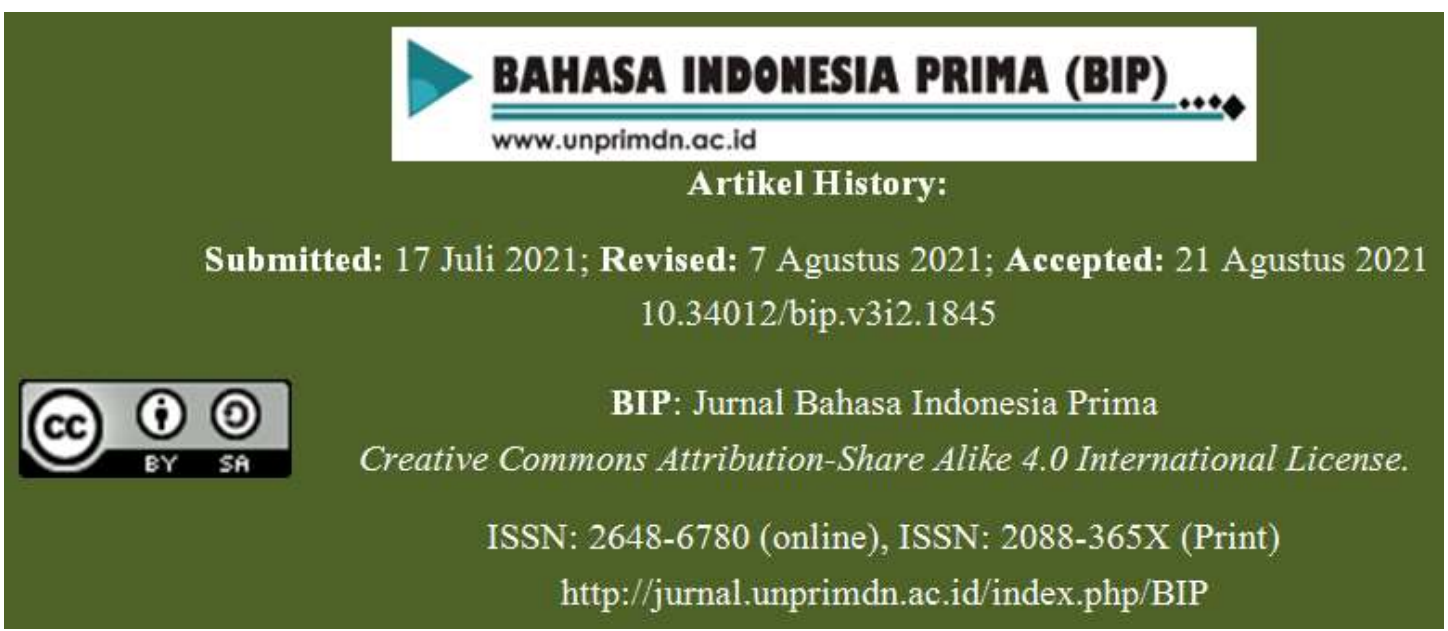

Abstrak-Penelitian ini dilatarbelakangi oleh adanya kendala saat siswa menulis puisi, bukubuku kumpulan puisi terbatas, dan penggunaan media pembelajaran kurang kreatif.Penelitian ini bertujuan untuk mengetahui pengaruh penggunaan media lagu Fiersa Besari terhadap kemampuan menulis puisi pada siswa kelas X di SMAN 19 Bekasi.Metode yang digunakan dalam penelitian ini adalah quasi eksperimentaldengan desain nonequivalent control group.Penelitian ini mengambil sampel sebanyak 37 siswa pada kelas X Mia 1 sebagai kelas eksperimen dan 37 siswa pada kelas Mia 6 sebagai kelas kontrol. Teknik pengolahan data dan analisis data menggunakan program SPSS 20.0 forwindows. Berdasarkan hasil penelitian, diperoleh bahwa rata-rata kemampuan menulis puisi kelas eksperimen lebih tinggi dibandingkan kelas kontrol. Rata-rata nilai pretest kelas kontrol sebesar 60,95, sedangkan rata-rata nilai pretest kelas eksperimen sebesar 69,59. Selanjutnya, rata-rata nilai posttest kelas kontrol sebesar 73,65, sedangkan rata-rata nilai posttest kelas eksperimen sebesar 80,14. Dengan demikian, media lagu Fiersa Besari berpengaruh terhadap kemampuan menulis puisi.Hal ini terbukti dengan hasil uji perbedaan dua rata-rata pada hasil posttest sebesar 0,001, maka Hoditolak dan Ha diterima.

Kata kunci: kemampuan menulis, puisi, media, lagu

Abstract-This study is motivated by the obstacles when students write poetry, limited poetry collection books, and the use of learning media is less creative. This study aims to determine the effect of using Fiersa Besari's song media on the ability to write poetry in class $X$ students at SMAN 19 Bekasi. The method used in this study is a quasi-experimental design with a nonequivalent control group. This study took a sample of 37 students in class X Mia 1 as the experimental class and 37 students in class X Mia 6 as the control class. Data processing and data analysis technique using SPSS 20.0 for windows program. Based on the results of the 
study, it was found that the average poetry writing ability of the experimental class was higher than the control class. The average pretest value of the control class was 60.59, while the average pretest value of the experimental class was 69.59. Furthermore, the average posttest score for the control class was 73.65, while the average posttest score for the experimental class was 80.14. Thus, the media of the song Fiersa Besari influences the ability to write poetry. This is evidenced by the results of the two average differences in the posttest results of 0.001, then Ho is rejected and Ha is accepted.

Keywoards: writing skills, poetry, media, song

\section{A. Pendahuluan}

Manusia merupakan makhluk sosial yang perlu berinteraksi dengan yang lainnya. Dalam berinteraksi membutuhkan alat, sarana, atau media, yaitu bahasa.Secara umum, bahasa dapat didefinisikan sebagai alat komunikasi verbal.Istilah verbal mengandung pengertian bahwa bahasa yang digunakan sebagai alat komunikasi pada dasarnya adalah lambang-lambang bunyi yang bersistem, yang dihasilkan oleh artikulator manusia, dan sifatnya arbitrer serta konvensional. Lambang-lambang bunyi bahasa dikatakan bersistem karena lambang-lambang itu dalam strukturnya menuruti kaidah-kaidah dan hierarki tertentu (Tambupulon, 2015: 1). Bahasa disusun secara teratur berpola yang membentuk suatu keseluruhan sehingga dapat bermakna atau berfungsi.

Keterampilanberbahasa (language skills) mempunyai empat komponen, yaitu keterampilan menyimak (listening skills), keterampilan berbicara (speaking skills), keterampilan membaca (reading skills), dan keterampilan menulis (writing skills) (Tarigan, 2008: 1). Dalam memperoleh keterampilan berbahasa biasanya melalui suatu hubungan urutan yang teratur. Pada masa kecil belajar menyimak atau mendengarkan bahasa, kemudian berbicara, setelah itu belajar membaca dan menulis. Keterampilan menyimak dan membaca bersifat reseptif, sedangkan keterampilan berbicara dan menulis bersifat produktif. Keempat keterampilan tersebut berhubungan sangat erat dengan proses berpikir yang mendasari bahasa.

Dalam kehidupan modern ini, keterampilan menulis sangat dibutuhkan. Keterampilan menulis adalah kemampuan mengungkapkan gagasan, pendapat, dan perasaan kepada pihak lain melalui bahasa tulis. Ketepatan pengungkapan gagasan harus didukung dengan ketepatan bahasa yang digunakan, kosakata dan gramatikal, serta penggunaan ejaan (Abbas, 2006: 125). Keterampilan menulis sangat penting bagi pengembangan diri siswa, baik untuk melanjutkan studi ke lembaga pendidikan yang lebih tinggi maupun untuk terjun ke masyarakat. Terkait dengan menulis sebagai salah satu aspek berbahasa dalam pembelajaran bahasa dan sastra Indonesia, siswa dituntut untuk mampu menuangkan ide, pikiran, dan perasaannya dalam berbagai bentuk tulisan, baik sastra maupun non sastra. Salah satu tulisan dalam ranah sastra adalah puisi.

Menulis puisi merupakan kegiatan menulis yang bersumber dari pengalaman atau imajinasi dengan penuh makna dan bernilai seni. Menulis puisi bukan keterampilan yang dapat diwariskan, tetapi hasil proses belajar dan berlatih. Pembelajaran menulis puisi di SMAN 19 Bekasi terdapat beberapa permasalahan. Ketika menulis puisi terkadang siswa mengalami kendala, seperti sulit 
menuangkan ide dan sulit memilih kata serta gaya bahasa yang tepat. Di samping itu, buku-buku kumpulan puisi di perpustakaan sekolah terbatas.

Pada masa pandemi Covid-19 seperti saat ini, guru harus mengoptimalkan media pembelajaran yang kreatif agar siswa tidak merasa jenuh selama pembelajaran menulis puisi berlangsung. Oleh karena itu, peneliti akan menggunakan media audio berupa lagu dalam pembelajaran menulis puisi. Penelitian dilakukan secara daring dengan menggunakan whatsapp grup, google meet, google classroom, dan google formulir.

Media audio untuk pembelajaran adalah bahan yang mengandung pesan dalam bentuk auditif yang dapat merangsang pikiran, perasaan, perhatian, dan kemauan siswa sehingga terjadi proses belajar mengajar (Sudjana, 2003: 129). Media lagu merupakan salah satu media audio yang dianggap efektif untuk menarik perhatian siswa. Lagu atau musik dapat meningkatkan fungsi kerja otak manusia, seperti membuat saraf-saraf otak bekerja serta menciptakan rasa nyaman dan tenang sehingga fungsi kerja otak menjadi optimal. Rangsangan ritmis dari lagu yang didengarkan tersebut yang dapat meningkatkan kemampuan berbahasa, kreativitas, konsentrasi, dan daya ingat (Aizid, 2011: 17).

Pada masa kini lagu indie sedang meraih popularitas karena lahirnya musisimusisi indie baru dengan lagu yang lebih modern, sehingga banyak digemari kalangan anak muda.Salah satu musisi indie yang sedang viral yaitu Fiersa Besari. Belakangan ini lagu-lagu karya Fiersa meramaikan platform musik, mulai dari youtube, joox, dan spotify. Setiap lirik lagu Fiersa memiliki makna yang mendalam, dan lagu-lagu yang dibawakan olehnya didominasi dengan nuansa sendu sehingga dapat menyentuh hati para pendengarnya.

Sehingga, upaya peneliti dalam mewujudkan proses pembelajaran lebih menarik dan meningkatkan kemampuan menulis puisi siswa adalah dengan menggunakan media lagu Fiersa Besari.

\section{B. Metode Penelitian}

Pendekatan dalam penelitian ini adalah pendekatan kuantitatif. Penelitian kuantitatif merupakan data penelitian berupa angka-angka dan analisis menggunakan statistik. Penelitian kuantitatif digunakan untuk meneliti populasi atau sampel tertentu dengan tujuan untuk menguji hipotesis yang telah ditetapkan. Penelitian ini menggunakan metode penelitian quasi eksperimental dengan desain nonequivalent control group. Desain ini terdiri atas kelompok eksperimen dan kelompok kontrol yang tidak dipilih secara random. Metode penelitian eksperimen digunakan untuk mencari pengaruh perlakuan tertentu terhadap suatu objek.

Desain Nonequivalent Control Group Design dapat digambarkan sebagai berikut.

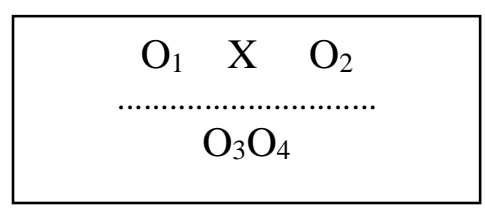

Keterangan:

$\mathrm{O}_{1}=$ pretest kelompok eksperimen

$\mathrm{O}_{2}=$ posttest kelompok eksperimen

$\mathrm{O}_{3}=$ pretest $\mathrm{kelompok}$ kontrol

$\mathrm{O}_{4}=$ posttest kelompok kontrol

$\mathrm{X}=$ treatment/perlakuan

Sumber: Sugiyono $(2017,79)$

Teknik pengumpulan data dilakukan dengan memberikan instrumen tes dan instrumen nontes. Teknik pengolahan data dan analis data dihitung dengan 
menggunakan program SPSS 20.0 for windows.

\section{Hasil dan Pembahasan}

Hasil penelitian mendapatkan nilai rata-rata pretest pada kelas eksperimen sebesar 69,59 dan nilai rata-rata posttest pada kelas eksperimen sebesar 80,14. Hasil ini menunjukkan bahwa terdapat peningkatan nilai rata-rata kemampuan menulis puisi pada kelas eksperimen sebelum dan sesudah diberi perlakuan media lagu Fiersa Besari. Sementara itu, nilai rata-rata pretest pada kelas kontrol sebesar 60,95 dan nilai rata-rata posttest pada kelas kontrol sebesar 80,14. Hasil ini menunjukkan bahwa terdapat peningkatan nilai rata-rata kemampuan menulis puisi pada kelas kontrol, tetapi peningkatan tersebut tidak sebesar peningkatan nilai rata-rata di kelas eksperimen.Hal itu disebabkan karena kelas kontrol tidak diberikan perlakuan berupa media lagu Fiersa Besari.

Hasil pengujian dalam penelitian ini melalui tiga tahapan. Tahap pertama yaitu melakukan uji normalitas. Uji normalitas dilakukan terhadap data pretest dan posttest dengan menggunakan uji Kolmogorov-Smirnov. Jika nilai signifikansi (Sig.)>0,05, maka data berdistribusi normal. Sebaliknya, jika nilai signifikansi (Sig.) $<0,05$, maka data berdistribusi tidak normal. Berdasarkan hasil perhitungan, kelas eksperimen memporelah nilai signifikansi data pretest sebesar 0,072 dan data posttest sebesar 0,061, maka data berdistribusi normal karena nilai signifikansi (Sig.) $>0,05$. Sementara itu, kelas kontrol memporelah nilai signifikansi data pretest sebesar 0,061 dan data posttest sebesar 0,081, maka data berdistribusi normal karena nilai signifikansi (Sig.) $>0,05$.
Tahap kedua yaitu melakukan uji homogenitas. Uji homogenitas dilakukan dengan menggunakan uji Levene. Jika nilai signifikansi (Sig.)>0,05, maka data homogen. Sebaliknya, jika nilai signifikansi (Sig.) $<0,05$, maka data tidak homogen. Berdasarkan hasil perhitungan, kelas eksperimen dan kelas kontrol memperoleh nilai signifikansi data pretest sebesar 0,053, maka data sampel berasal dari populasi yang memiliki varian yang sama (homogen) karena nilai signifikansi (Sig.) $>0,05$. Sementara itu, kelas eksperimen dan kelas kontrol memperoleh nilai signifikansi data posttest sebesar 0,060, maka data sampel berasal dari populasi yang memiliki varian yang sama (homogen) karena nilai signifikansi (Sig.) $>0,05$.

Tahap ketiga yaitu melakukan uji perbedaan dua rata-rata (Uji-t).Jika nilai sig. (2-tailed) >0,05, maka Ho diterima dan Ha ditolak. Sebaliknya, jika nilai sig. $(2$-tailed $)<0,05$, maka Ho ditolak dan $\mathrm{Ha}$ diterima. Berdasarkan hasil perhitungan, kelas eksperimen dan kelas kontrol memperoleh nilai Sig. (2-tailed) data posttest sebesar 0,001, maka Ho ditolak dan Ha diterima karena nilai Sig. (2tailed $)<0,05$. Artinya, penggunaan media lagu Fiersa Besari berpengaruh terhadap kemampuan menulis puisi pada siswa kelas X di SMAN 19 Bekasi.

\section{Simpulan}

Berdasarkan hasil analisis dan pembahasan sebelumnya, peneliti menyimpulkan bahwa penggunaan media lagu Fiersa Besari dapat meningkatkan kemampuan menulis puisi siswa. Hal ini dapat dilihat dari hasil rata-rata posttest kelas eksperimen dengan skor 80,14> dari posttest kelas kontrol dengan skor 73,65. Selanjutnya, Uji-t menunjukkan bahwa antara kelas eksperimen dan kelas kontrol 
BIP: Jurnal Bahasa Indonesia Prima Vol. 3, No. 2, 2021, September 2021, PP.

terdapat perbedaan yang signifikan. Hasil dari Uji-t yaitu nilai Sig. (2-tailed)<0,05 dengan skor 0,001. Artinya, penggunaan media lagu Fiersa Besari terbukti berpengaruh terhadap kemampuan menulis puisi pada siswa kelas X di SMAN 19 Bekasi.

\section{Daftar Pustaka}

Tarigan, H. G. 2008. Menulis sebagai suatu keterampilan berbahasa. Bandung: Angkasa Bandung.

Abbas, S. 2006. Pembelajaran Bahasa Indonesia yang Efektif di Sekolah Dasar. Jakarta: Departemen Pendidikan Nasional.

Sudjana, N. 2003. Penilaian Hasil Proses Belajar Mengajar. Bandung: PT. Remaja Rosdakarya.

Aizid. 2011. Sehat dan Cerdas dengan Terapi Musik. Yogyakarta: Laksana.

Sugiyono. 2017. Metode Penelitian Kuantitatif, Kualitatif, dan $R \& D$. Bandung: Alfabeta. 